\title{
FOSTER CARE AS AN ELEMENT OF SOCIAL ASSISTANCE
} Karolina Walancik-Ryba ${ }^{1}$

DOI: https://doi.org/10.24040/pros.13.11.2020.ssp.224-230

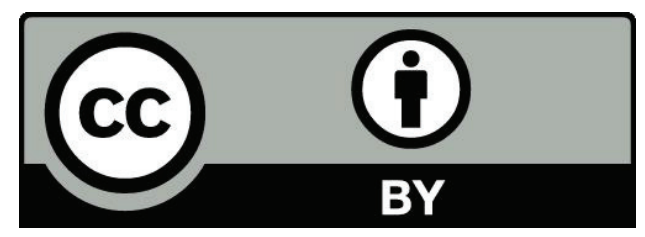

\begin{abstract}
The article "Foster care as an element of social assistance" deals with the issues related to the foster family treated as an element of the legal system in force in Poland regarding social assistance. Foster care in Poland is implemented in one of the family forms of foster care, which is a foster family. The author analyzes the functioning of this institution and the forms of its support, both on the basis of the applicable provisions of law and in practice, on the basis of court files conducted in court. In addition, it presents villages regarding the applicable regulations in the field of social assistance and their functioning in judicial practice.
\end{abstract}

\section{Keywords}

Family. Social welfare systém. Foster family. Child. Foster care. Parents.

\section{Foster care as an element of social assistance.}

Man is a social being ${ }^{2}$ and his first, natural environment for the care and education of man is the family. Therefore, there is no doubt that the task of providing a child with appropriate care, safety, development and upbringing is primarily the responsibility of parents.

The right of a child to be brought up by parents, known as the right of a child to a family $^{3}$ comes from, inter alia, from the Convention on the Rights of the Child, ratified by Poland on June 7, 1991 ${ }^{4}$. The parents are primarily responsible for the child. In certain situations, for various reasons, depending or beyond the parents' control, they do not fulfill this task or fulfill it incorrectly.

\footnotetext{
${ }^{1}$ Dr. Karolina Walancik-Ryba - WSB University in DąbrowaGórnicza, Poland.

${ }^{2}$ E. Aronson, Człowiek istota społeczna, Wydawnictwo Naukowe PWN, Warszawa 2009, s. 14.

${ }^{3}$ B. Gudbrandsson, Dzieci w instytucjach opiekuńczych: zapobieganie instytucjonalizacji $i$ alternatywne formy opieki w krajach europejskich, Government Agency for Child Protection, Islandia, s. 5.

4 Konwencja o prawach dziecka przyjęta przez Zgromadzenie Ogólne Narodów Zjednoczonych dnia 20 listopada 1989 r. (Dz.U. 1991.120.526).
} 


\section{PRÁVNE ROZPRAVY ON-SCREEN II. - Sekcia súkromného práva}

online vedecká konferencia - 13. november 2020

The issues related to supporting the family as part of social assistance were regulated in the Act of March 12, 2004 on social assistance ${ }^{5}$, this changed with the entry into force of the Act of June 9, 2011 on supporting the family and foster care system ${ }^{6}$, which regulates the issues of organization and functioning of institutions supporting the family and foster care.

Among the forms of family support introduced by the Act on supporting the family, a significant role is played by assistantships, day support centers and supporting families, aimed primarily at helping children and families in their natural environment. It is impossible to solve the problems of children and adolescents, ignoring the problems of the whole family. One of the most important and revolutionary solutions seems to be especially the introduction of the function of a family assistant, which is to act as a kind of intermediary between the family and the institutions supporting it. The main task of the assistant is to prevent the separation of the child from the family, or to bring about the return from the so-called foster care. The contemporary system of supporting the family and the child presupposes the need to provide each child with a stable and lasting educational environment that can only be created by a natural family. The implementation of this task has been assigned to local government institutions which, through various forms of family support, should enable children to be brought up in biological families. Assistantships, activities of day support centers and supporting families are of the nature of community help for dysfunctional families. These new forms of family support are a response to the adopted assumption of the reformed family support system about the need to place the main emphasis on keeping children in their natural environment, as well as the need to strengthen preventive measures and improve methods of working with the family in order to improve its situation.

The consequence of the parents' failure to fulfill their obligations at all or properly may be a situation in which the child's further stay in the family poses a threat to his "welfare" / interest. In such cases, it is the responsibility of the State to provide the child with care which, for various reasons, is not provided by the parents.

Interference in the sphere of parental custody (authority) is an exceptional situation, limited to preventing the unfavorable situation of a child staying in the family ${ }^{7}$ and taking into account the best interests of the child. And the responsibility of the state is subsidiary,

\footnotetext{
${ }^{5}$ Ustawa z dnia 12 marca 2004 r. o pomocy społecznej (Dz. U. 2004 Nr 64 poz. 593).

${ }^{6}$ Ustawa z dnia 9 czerwca 2011r. o wspieraniu rodziny i systemie pieczy zastępczej (Dz. U. $2011 \mathrm{Nr} 149$ poz. 887) zwanej dalej ustawą o wspieraniu rodziny.

${ }^{7}$ art. 9 ust. 1 Konwencji o Prawach Dziecka.
} 


\section{PRÁVNE ROZPRAVY ON-SCREEN II. - Sekcia súkromného práva}

online vedecká konferencia - 13. november 2020

expressed mainly in legislative and administrative activities aimed at providing the child with goods that are not able to provide them by their parents. - best interests of the child ${ }^{8}$.

When the child is separated from the family, the task of providing the child with foster care in relation to parental care appears. According to the regulations in force in Poland, foster care is provided in two forms: family and institutional. Family foster care can be exercised in two forms, i.e. in the form of a foster family or in the form of a family children's home ${ }^{9}$. The first of them can be exercised as part of a foster family: related, non-professional, professional - including a family emergency and professional specialist, and among them families: therapeutic (for children with health deficits) ${ }^{10}$, social rehabilitation (for socially maladjusted children and adolescents, for whom a court judgment for minors and for underage mothers with children has been issued) ${ }^{11}$. Institutional foster care may be exercised in care and education centers, regional care and therapy centers, and pre-adoption intervention centers ${ }^{12}$.

Preferences for family forms of foster care result from the provisions of international law in force in Poland - the Convention on the Rights of the Child ${ }^{13}$,,as well as comply with EU standards: Resolution No. (77) 33 of the Committee of Ministers of the Council of Europe on placing children outside the family. ${ }^{14}$

With reference to the above subject, the author analyzed the legal acts in force in Poland regarding foster families and the court practice in cases concerning the placement of a child in a foster family. As the justification for conducting the research, he indicated the changes introduced to the hitherto existing system of foster care, as well as the controversy and the growing wave of criticism in the public opinion of family courts regarding the selection of foster care for children.

The author analyzed a total of one hundred and fifteen cases resolved by individual district courts of the Katowice district, in which a decision was made to place the child in a foster family. Based on the data obtained from the statistical reports of the District Court in Katowice in 2012-2014, six hundred and nine decisions were issued regarding the placement

\footnotetext{
${ }^{8}$ art. 3 Konwencji o Prawach Dziecka.

${ }^{9}$ art. 39 ustawy o wspieraniu rodziny.

10 Ustawa z dnia 27 sierpnia 1997 r. o rehabilitacji zawodowej i społecznej oraz zatrudnianiu osób niepełnosprawnych, (Dz.U. 1997 nr 123 poz. 776 z późn. zm.).

11 art. 39 ustawy o wspieraniu rodziny; M. Andrzejewski (w:) M. Andrzejewski, H. Dolecki, J. Haberko, A. Lutkiewicz-Rucińska, A. Olejniczak, T. Sokołowski, A. Sylwestrzak, A. Zielonacki, red. H. Dolecki, T. Sokołowski, Kodeks Rodzinny i Opiekuńczy, Wolters Kluwer SA, Warszawa 2013, s .771.

12 art. 93 ustawy o wspieraniu rodziny.

13 art. 20 ust. 3 Konwencji.

14 art. $112^{2}$ k.r.o.; ustawa z dnia 25 lipca 2014 r. o zmianie ustawy o wspieraniu rodziny i systemie pieczy zastępczej oraz niektórych innych ustaw (Dz.U. 2014 poz. 1188).
} 


\section{PRÁVNE ROZPRAVY ON-SCREEN II. - Sekcia súkromného práva}

online vedecká konferencia - 13. november 2020

of a child in a foster family. ${ }^{15}$ The Katowice district is the largest court district in Poland and includes as many as 14 district courts with its jurisdiction.

There is no definition of the terms: foster care, foster family in Polish legislation. There is also no legal definition of the term family. Law on supporting the family does not contain a definition of the care system, it only indicates the purpose of the foster care system, which is to provide temporary care and upbringing to the child in cases where parents are unable to provide care and upbringing. The research analysis also shows that foster care is also not current care, parental custody or custody within the meaning of the Civil Code.

Moreover, a child placed in a foster family still remains a child of his parents with all the alimony, inheritance. The child's marital status does not change, it has the status of a household member. The child does not have a parental bond with a foster family,but only a legal bond, sometimes an emotional bond.

As it results from the conducted research, the legislator focused especially on supporting professional foster families, including specialist professional foster families, and secondly on supporting non-professional foster families. The above-mentioned concentration consists in preferring this type of foster families to related foster families, both in terms of financial resources and in terms of assistance provided to these families in performing their functions. As far as financial support is concerned, in accordance with the Act on Family Support, professional foster families are entitled to higher benefits to cover the cost of child maintenance than related foster families. Professional foster families may receive financial resources for the maintenance of a flat, as well as receive a benefit to cover the costs related to the necessary renovation of a flat. The professional foster family is also entitled to remuneration for performing their function. In addition, she can benefit from training, support from a helping family or a person to help with childcare and farm work.

In most of the analyzed cases, the court, when deciding to place the child in a foster family, interfered with the parents' parental authority - most often by limiting it. The practice of courts consisting in not depriving parents of parental authority, but only limiting it in situations where the attitude of the child's parents does not indicate that it will ever improve, as was the case in most of the cases analyzed by me, causes difficulties in the proper custody of the child in related to the scope of the division of powers and duties between the foster family and the child's parents.

15 Dane ze sprawozdań statystycznych MS-S16r oraz MS-S18 za lata 2012-2014 (pismo Prezesa Sądu Okręgowego w Katowicach Prez.008-111/15 z dnia 8 kwietnia 2015 r.). 


\section{PRÁVNE ROZPRAVY ON-SCREEN II. - Sekcia súkromného práva}

online vedecká konferencia - 13. november 2020

As shown by the research, in practice, a child is most often placed in a foster family formed by grandparents who take care of it, raise it and take care of it, often from birth. Siblings are very often placed in foster families: two, three, four or even five children. It should also be emphasized that even in situations where a child has a disability certificate, requires constant medical care, or has created educational problems, it goes in practice to a related foster family, and not to a specialist foster family.

Children are very rarely placed in professional foster families. This is due to the fact that there are not enough professional foster families, moreover, they often also act as emergency care, so they go to these families of children in emergency situations for a short period of time. Courts often choose between placing the child in the "imperfect", but emotionally connected with the child, a related or non-professional foster family, most often created by persons who are related or related to the child, and placing the child in a care and educational institution.

In the draft act on supporting the family, the legislator assumed the strengthening of preventive measures and the improvement of methods of working with the family for the benefit of, inter alia, the return of the child to the family. The conducted research shows that the institution of a family assistant introduced by the legislator does not function properly, and cooperation with the child's family is ineffective or lacking, because only in one case the case files contained information about the assistant's cooperation with the family. Moreover, as the analysis shows, at the stage of conducting the research, none in some cases, a child placed in a foster family did not return to its parents, nor was it adopted. Foster care is therefore not temporary but it is permanent.

In conclusion, it should be acknowledged that the solutions contained in the applicable legal regulations concerning foster care in a foster family do not fully ensure the implementation of the goals and tasks of foster care, and thus do not contribute effectively to reducing family disintegration and the correct implementation of the child's right to upbringing in the family.

The reasons for this should be, first, the lack of precision of the legislator, who, bearing in mind that the issues related to foster care exercised in a foster family and the legal status of a child in a foster family is complicated and complex, should act in a more exact and consistent, treating the applicable legal system as a coherent whole. In addition, it is important that the legal solutions adopted by the legislator in the Act on supporting the family, which 


\section{PRÁVNE ROZPRAVY ON-SCREEN II. - Sekcia súkromného práva}

online vedecká konferencia - 13. november 2020

discriminate against relatives foster families in relation to professional and non-professional foster families, both in financial terms, as well as in terms of the possibility of using by these families the forms of substantive and physical assistance in performing their functions.

Summing up, it should be pointed out that in most of the analyzed cases, the decision to place a child in a foster family was a form of regulating the legal situation and legalizing the existing and previously shaped facts in the form of care and upbringing of children by grandparents, siblings, and further relatives, even not in every case. In the case of the case, it was optimal in terms of the child's individual needs, taking into account the emotional bond existing between the child and the foster family.

The guidelines for the legislator should be greater concentration on helping related foster families, because, as indicated, in practice they most often fulfill foster care over the child and provide the child with a stable care and educational environment. It should be emphasized that it is necessary to create such legal solutions that will provide the child with an optimal care and educational environment suitable for his needs. Enabling the implementation of the child's right to a family. The child's needs depend on the situation in which the child is located and on its individual characteristics, however, they do not depend on the type of foster family in which it is placed.

\section{Bibliography}

1. Andrzejewski M., Dolecki H., Haberko J., Lutkiewicz-Rucińska A., Olejniczak A., Sokołowski T., Sylwestrzak A., Zielonacki A., red. Dolecki H., Sokołowski T., Kodeks Rodzinny i Opiekuńczy, Wolters Kluwer SA, Warszawa 2013;

2. Aronson E., Człowiek istota społeczna, Wydawnictwo Naukowe PWN, Warszawa 2009;

3. Dane ze sprawozdań statystycznych MS-S16r oraz MS-S18 za lata 2012-2014 (pismo Prezesa Sądu Okręgowego w Katowicach Prez.008-111/15 z dnia 8 kwietnia 2015 r.);

4. Gudbrandsson B., Dzieci w instytucjach opiekuńczych: zapobieganie instytucjonalizacji i alternatywne formy opieki w krajach europejskich, Government Agency for Child Protection, Islandia;

5. Konwencja o prawach dziecka przyjęta przez Zgromadzenie Ogólne Narodów Zjednoczonych dnia 20 listopada 1989 r. (Dz.U. 1991.120.526); 


\section{PRÁVNE ROZPRAVY ON-SCREEN II. - Sekcia súkromného práva}

online vedecká konferencia - 13. november 2020

6. Ustawa z dnia 12 marca 2004 r. o pomocy społecznej (Dz. U. 2004 Nr 64 poz. 593);

7. Ustawa z dnia 9 czerwca 2011 r. o wspieraniu rodziny i systemie pieczy zastępczej (Dz. U. 2011 Nr 149 poz. 887) zwanej dalej ustawą o wspieraniu rodziny;

8. Ustawa z dnia 27 sierpnia 1997 r. o rehabilitacji zawodowej i społecznej oraz zatrudnianiu osób niepełnosprawnych, (Dz.U. 1997 nr 123 poz. 776 z późn. zm.);

9. Ustawa z dnia 25 lutego 1964 r. - Kodeks rodzinny i opiekuńczy (Dz.U.2020.0.1359 t.j);

10. Ustawa z dnia 25 lipca 2014 r. o zmianie ustawy o wspieraniu rodziny i systemie pieczy zastępczej oraz niektórych innych ustaw (Dz.U. 2014 poz. 1188). 